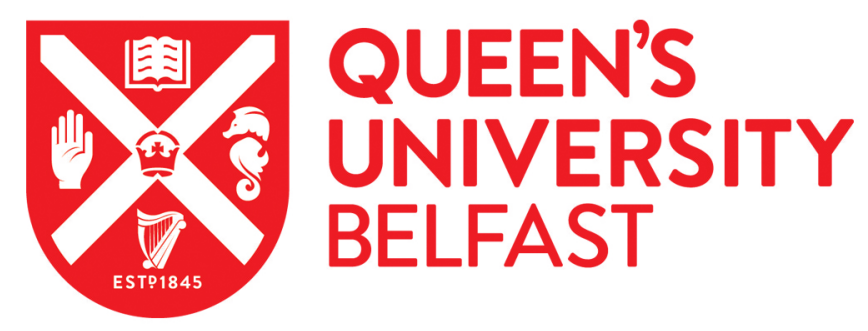

\title{
Development of a modified flyash as a permeable reactive barrier media for a former manufactured gas plant site Northern Ireland
}

Doherty, R., Phillips, D., McGeough, K., Walsh, K. P., \& Kalin, B. (2006). Development of a modified flyash as a permeable reactive barrier media for a former manufactured gas plant site Northern Ireland. Environmental Geology, 50(1)(1), 37-46. https://doi.org/10.1007/s00254-005-0170-4

Published in:

Environmental Geology

Queen's University Belfast - Research Portal:

Link to publication record in Queen's University Belfast Research Portal

\section{General rights}

Copyright for the publications made accessible via the Queen's University Belfast Research Portal is retained by the author(s) and / or other copyright owners and it is a condition of accessing these publications that users recognise and abide by the legal requirements associated with these rights.

Take down policy

The Research Portal is Queen's institutional repository that provides access to Queen's research output. Every effort has been made to ensure that content in the Research Portal does not infringe any person's rights, or applicable UK laws. If you discover content in the Research Portal that you believe breaches copyright or violates any law, please contact openaccess@qub.ac.uk. 


\section{R. Doherty \\ D.H. Phillips \\ K.L. McGeough \\ K.P. Walsh \\ R.M. Kalin}

\section{Development of modified flyash as a permeable reactive barrier medium for a former manufactured gas plant site, Northern Ireland}

Received: 1 July 2005

Accepted: 13 December 2005

(C) Springer-Verlag 2006
R. Doherty · D.H. Phillips

K.L. McGeough · K.P. Walsh

R.M. Kalin

Environmental Engineering Research Centre, School of Planning, Architecture, and Civil Engineering, Queen's University of Belfast, BT9 5AG Belfast,

Northern Ireland

D.H. Phillips $(\bowtie)$

Environment Agency, Contaminated Land Science Group, Olton Court, 10 Warwick Road, B92 7HX Olton, Solihull, UK

E-mail: d.phillips@qub.ac.uk

Tel.: + 44-28-90975590

Fax: + 44-28-90663754

\begin{abstract}
A sequential biological permeable reactive barrier (PRB) was determined to be the best option for remediating groundwater that has become contaminated with a wide range of organic contaminants (i.e., benzene, toluene, ethylbenzene, xylene and polyaromatic hydrocarbons), heavy metals (i.e., lead and arsenic), and cyanide at a former manufactured gas plant after 150 years of operation in Portadown, Northern Ireland. The objective of this study was to develop a modified flyash that could be used in the initial cell within a sequential biological PRB to filter complex contaminated groundwater containing ammonium. Flyash modified with lime $(\mathrm{CaOH})$ and alum was subjected to a series of batch tests which investigated the modified cation exchange capacity (CEC) and rate of removal of anions and cations from the solution. These tests showed that a high flyash composition medium $(80 \%)$ could remove 8.65 mol of ammonium contaminant for every kilogram of medium. The modified CEC procedure ruled out the possibility of cation exchange as the major removal mechanism. The
\end{abstract}

medium could also adsorb anions as well as cations (i.e., $\mathrm{Pb}$ and $\mathrm{Cr}$ ), but not with the same capacity. The initial mechanism for $\mathrm{Pb}$ and $\mathrm{Cr}$ removal is probably precipitation. This is followed by sorption, which is possibly the only mechanism for the removal of dichromate anions. Scanning electron microscopic analysis revealed very small $(<1 \mu \mathrm{m})$ cubic highly crystalline precipitates on the flyash, although this new crystalline zeolite growth did not occur rapidly enough to enable productive zeolite formation. Surface area measurements showed that biofilm growth on the medium could be a major factor in the comparative reduction of surface area between real and synthetic contaminant groundwaters. The modified flyash was found to be a highly sorptive granular material that did not inhibit microbiological activity, however, leaching tests revealed that the medium would fail as a long-term barrier material.

Keywords Flyash P Permeable reactive barrier - Reactive medium - Groundwater remediation $\cdot$ Northern Ireland

\section{Introduction}

Subsurface geological material and groundwater have become contaminated with a wide range of organic contaminants [i.e., benzene, toluene, ethylbenzene, xy- lene (BTEXs) and polyaromatic hydrocarbons (PAHs)], heavy metals (i.e., lead and arsenic), and cyanide at a former manufactured gas plant (FMGP) site after 150 years of operation in Portadown, Northern Ireland. A sequenced biological permeable reactive barrier (PRB) 
was determined to be the most cost-effective option for remediating the contaminated groundwater. An important step in creating the PRB was to develop a medium that could break down ammonia, which has been identified as an inhibiting inorganic oxygen competing contaminant that occurs with the majority of organic contamination at the Portadown FMGP site. Ammonium is a common inorganic contaminant that occurs with organic groundwater contamination at FMGP sites (also known as gasworks; ICRCL 1989), and may inhibit or reduce the effectiveness of biodegradation of aromatic organic contaminants. In an oxidizing environment, the transformation of ammonium to nitrate may remove the oxygen needed for microbial activity (Fenchel and Blackburn 1978). This problem can be overcome if ammonium is removed within the first sections of the sequenced barrier. If the sequenced biological barrier is to be used at this and other MGP sites, initial removal of ammonium to promote organic biodegradation may be a common step. The protocol that the medium design must follow is that it (1) has a high sorptive or exchange capacity, (2) has a continuous high porosity and permeability over its lifespan, (3) has the ability to promote or at least not inhibit microbial activity, and (4) should be economically viable.

There are a variety of low-cost media that have sorbing attributes that could possibly be used at the site. The sorbants can be grouped into three main areas: (1) biological origin, such as the PRB reactive media composed of a mixture of municipal composts, leaf mulch, wood chips and smaller amounts of gravel and limestone reported by Benner et al. (1999) and peat moss (Guerin et al. 2002), (2) mineralogical origin, such as zeolites (Park et al. 2002; Perić et al. 2004), $\mathrm{Fe}^{0}$ (Blowes et al. 1997; O'Hannesin and Gillham 1998; Puls et al. 1999; Roh et al. 2000; Phillips et al. 2000, 2003a, b; Gu et al. 2002), and laterites (Wood and McAtemney 1996) and, (3) synthetic origin, such as modified/synthetic flyash (Baltpurvins et al. 1996; Axe and Anderson 1998; Adasaka et al. 1998; Klemm 1998).

The initial idea was to develop a medium that would recycle a waste product; therefore, the raw material for the medium would be cheap and widely available. One waste material that could be modified into a possible medium was flyash. Flyash is a pozzolanic material that contains silica and basic metal oxides similar to volcanic tuffs (Cohen et al. 2003). In alkaline environments, the tuffs are transformed into zeolites, which have high cation exchange properties (Majcenovic and BarthWirsching 2000). Modified flyash or synthetic zeolites can be made from flyash by the addition of $\mathrm{NaOH}$ under pressure and heated to at least $100^{\circ} \mathrm{C}$ (Amrhein et al. 1996; Lin et al. 1998; Srinivasan and Grutzech 1999). Although the production of synthetic zeolites from flyash is currently uneconomic, they still have the potential to be developed into an exchange/sorbing media
(Reardon and Della Valle 1997). Reardon and Della Valle (1997) in an attempt to recycle flyash, treated it with lime $(\mathrm{CaOH})$ and formed an anionic clay, which due to its solid solution nature has the ability to substitute divalent and trivalent cations within its octahedral layers and the ability to substitute anions in the mineral interlayers. Blowes et al. (2000) highlighted the need for a material that can sorb both cations and anions. This anionic clay quality is similar to the exchange characteristics of zeolites. Such anionic clays may be the precursors or parent material of zeolites. The objective of the current research was to develop a modified fly ash that could be used in the initial cell within a sequential biological PRB to treat complex contaminated groundwater containing ammonium.

\section{Materials and methods}

Analysis of flyash

Flyash was obtained from a peat burning power station at Shannonbridge Ireland from the Electricity Supply Board (ESB). The majority of the flyash from peat burning power stations is landfilled after being separated in settling ponds. The flyash was prepared for analysis according to the fusion procedure where moisture free samples are mixed with an equal ratio of $\mathrm{Li}_{2} \mathrm{~B}_{4} \mathrm{O}_{7}$ and $\mathrm{LiBO}_{2}$. Then, the fused material is dissolved in a ratio of 1:8 hot $\mathrm{HCl}$ acid (DOT 1998) and analysed by inductively coupled plasma atomic emission spectroscopy (ICP-AES) (Perkin Elmer, Wellesley, MA, USA).

\section{Batch tests-modified ion exchange}

Cation exchange capacity (CEC) determination for clay minerals was modified from Kempers and Zweers (1986). Triplicate batches of about $0.5 \mathrm{~g}$ of medium were measured into $10 \mathrm{ml}$ of $1 \mathrm{M}$ ammonium acetate. This was shaken for $24 \mathrm{~h}$ and filtered using Whatman glass microfilter paper under slight vacuum. The supernatant was kept for high- pressure liquid chromatography-ion chromatography (HPLC-IC) analysis (Dionex DX 500, Dionex Corp., Sunnyvale, CA, USA), the reduction in ion concentration is attributed to sorption by the medium surface. $\mathrm{A} \mathrm{NaCl}(1 \mathrm{M})$ solution was acidified by dropwise addition of $\mathrm{HCl}$ until measured at $\mathrm{pH} 2.5$. This solution should have greater cation exchange selectivity and should displace cations previously sorbed to the medium surface. The filtrate was washed with this solution until $50 \mathrm{ml}$ of extract was recovered. This second supernatant was also retained for HPLC-IC analysis. Analysis of the initial solutions before contact with the medium compared to the supernatants should give an idea of the ion exchange capacity of the medium. The samples were run in triplicate with blanks to determine 
ion sorption to glass, and excess ions already present in the medium. This procedure was chosen primarily because it determines cation exchange capacity using ammonium acetate. This concurs with the specific inorganic groundwater contaminant (ammonium) that this medium is designed to remove. The two barrier media mixtures, M003 and M004, with differing compositions were used to determine whether a high- alum or highflyash mixture would provide a better ion scavenging medium (Table 1).

The samples were diluted, and analysed in triplicate using a Dionex AS3500 autosampler with Dionex GP50 pump through a Dionex CS12A $4 \mathrm{~mm}$ ion column and Dionex CD20 conductivity detector. A sample size of $100 \mu \mathrm{l}$ was required for analysis. All samples were filtered through $0.2 \mu \mathrm{m}$ Anotop syringe filters. The mobile phases were run isocratically at a flow rate of $1 \mathrm{ml} \mathrm{min}^{-1}$ with $20 \mathrm{mM}$ methane sulphonic acid solution through the exchange column. De-ionised water blanks were run every five to six samples. The supernatants were analysed for ammonium and sodium cations. Sulphate was analyzed by the KONE Analyser (APHA 1992) and by HPLC-IC.

The ammonium was analysed according to (APHA 1992). The $1 \mathrm{M}$ stock solutions used in the modified exchange procedure were also analysed. An error relative standard deviation of $4.144 \%$ was determined for ammonium and $4.413 \%$ was determined for sodium. A dilution factor of 500 and the tendency of ammonium to degrade over time were seen as the major possible sources of error in the procedure. The experiment was repeated using a glass blank, i.e. no medium was used, to determine possible error in the procedure from sorption of ammonium and sodium to glass and error in dilution in preparation for HPLC-IC to determine ammonium concentration.

The removal rate of heavy metals, $\mathrm{Pb}$ and $\mathrm{Cr}$, from solution by contact with barrier medium was tested in triplicate. About $1 \mathrm{~g}$ of M003 was accurately weighed and added to a beaker containing $20 \mathrm{ml} 0.01 \mathrm{M}$ lead nitrate solution and agitated. Two hundred microlitres of supernatant were sampled at regular intervals for about 25 min over $4 \mathrm{~h}$, then diluted, filtered, and acidified in preparation for inductively coupled plasma optical emission spectroscopy (ICP-OES) analysis (Perkin Elmer PE 400, Wellesley, MA, USA). The samples were also analysed in triplicate by ICP-OES, allowing standard deviation to be calculated from a group of nine samples. This procedure was repeated with potassium dichromate solution.

\section{SEM analysis}

Scanning electron microscopic (SEM; Jeol JSM 6400 Scanning Electron Microscope) observations were made of powdered M003 to determine whether new crystalline growth occurred.

Geochemical modelling of synthetic and MGP contaminated groundwater

To model precipitation between M003 and groundwater in column experiments, the equilibrium geochemical model Visual Minteq (Gustaffoson 2001) was used to determine speciation in gasworks and to develop synthetic groundwater. The majority of the groundwater to be used in the experiments was from a piezometer emplaced within test pit 11 (TP 11) on the site. Analysis of the major components of TP11 was used as input data (Table 2). From the conceptual biogeochemical model, manganese, iron, and sulphate redox geochemistry was allowed to occur within the numerical geochemical model. Total organic carbon (TOC) from the analysis was used as dissolved organic matter (DOM). Trace metal chemistry by ICP-AES and $\mathrm{Eh}$ and $\mathrm{pH}$ values from field measurements was also included in the model.

Surface area measurements of media

Two column experiments were set up with the granular medium: one using contaminated groundwater from the Portadown FMGP site, and the other using synthetic groundwater. Unfortunately, the HPLC was undergoing an extended period of malfunction, during which time the column samples degraded. To recalibrate the instrument, seven certified standards were run in triplicate and new calibration graphs were constructed for each ion. It was noticed that within the column with the contaminated groundwater, there was biomass growing. This result was not apparent within the column containing synthetic groundwater. A comparison between

Table 1 Composition of the modified flyash mixture and removal of ammonium by media mixtures

\begin{tabular}{lllllll}
\hline Media & $\begin{array}{l}\text { Ash } \\
\text { content } \\
(\%)\end{array}$ & $\begin{array}{l}\text { Lime } \\
\text { content } \\
(\%)\end{array}$ & $\begin{array}{l}\text { Alum } \\
\text { content } \\
(\%)\end{array}$ & $\begin{array}{l}\text { Ammonium } \\
\text { Removed } \\
\left(\mathrm{mg} \mathrm{kg}^{-1}\right)\end{array}$ & $\begin{array}{l}\text { Ammonium } \\
\text { exchanged } \\
\left(\mathrm{mg} \mathrm{kg}^{-1}\right)\end{array}$ & $\begin{array}{l}\text { \% Relative standard } \\
\text { deviation (RSD) }\end{array}$ \\
\hline M003 & 80 & 10 & 10 & 8.65 & 0.068 & 1.35 \\
M004 & 10 & 10 & 80 & 6.11 & 0.073 & 1.71 \\
\hline
\end{tabular}


Table 2 Input values used for geochemical modelling of gasworks contaminated groundwater (Trial Pit 11) with $\mathrm{pH}$ of 7.03 and $\mathrm{Eh}$ of $3.28 \mathrm{mV}$

\begin{tabular}{lll}
\hline Component & Groundwater & \\
\cline { 2 - 3 } & FMGP $\left(\mathrm{mg} \mathrm{l}^{-1}\right)$ & Synthetic $\left(\mathrm{mg} \mathrm{l}^{-1}\right)$ \\
\hline $\mathrm{SO}_{4}^{2-}$ & 669 & \\
$\mathrm{~S}$ & 8.1 & \\
$\mathrm{CN}^{-}$ & 3.73 & \\
$\mathrm{AsO}_{4}^{3-}$ & 0.2 & \\
$\mathrm{Ba}^{2+}$ & 0.40 & \\
$\mathrm{Cr}^{2+}$ & 0.03 & \\
$\mathrm{Zn}^{2+}$ & 0.19 & \\
$\mathrm{~Pb}^{2+}$ & 0.01 & \\
$\mathrm{Ni}^{2+}$ & 0.18 & \\
$\mathrm{Fe}^{2+}$ & 0.95 & 15 \\
$\mathrm{Mn}^{2+}$ & 1.39 & 100 \\
$\mathrm{Cu}^{2+}$ & 0.14 & 1,000 \\
$\mathrm{Ca}^{2+}$ & 112 & \\
$\mathrm{Na}^{+}$ & 33 & 30 \\
$\mathrm{~K}^{+}$ & & 50 \\
$\mathrm{Mg}^{2+}$ & 21.5 & 1,000 \\
$\mathrm{NO}_{3}^{-}$ & & \\
$\mathrm{CO}_{3}^{2-}$ & & \\
$\mathrm{Cl}^{-}$ & 39 & \\
$\mathrm{Fe}^{3+}$ & Redox allowed \\
$\mathrm{HS}^{-1}$ & Redox allowed \\
$\mathrm{Mn}^{3+}$ & Redox allowed \\
$\mathrm{DOM}^{2+}$ & 94 & \\
\hline
\end{tabular}

the relative surface areas of the column with biomass, the column without biomass, and a fresh sample was believed to be an indicator of the possible effect of biomass growth on the sorption characteristics, and hence, lifespan of the barrier. A Sorptomatic 1990 was used to measure the surface area of the samples. This instrument measures surface area by flooding a dry, degassed sample with nitrogen and measuring the amount of nitrogen that sorbs and desorbs to the medium surface.

Three samples were oven dried at $110^{\circ} \mathrm{C}$ for a period of 3-4 days to remove all water sorbed to the medium surface. The Sorptomatic burette was degassed, heated to $110^{\circ} \mathrm{C}$, sealed and weighed. About $3-4 \mathrm{~g}$ of ovendried sample was added to the burette; the burette was reattached to the Sorptomatic, heated at $110^{\circ} \mathrm{C}$ for a period of $2 \mathrm{~h}$ and degassed. The sealed burette was heated again and the degassed sample was reweighed. The nitrogen reservoir and burette sleeve were filled with liquid nitrogen. The sealed burette was reattached to the Sorptomatic 1990 and placed in the sleeve containing liquid nitrogen. The system was degassed, the seal on the burette was opened, and the sleeve was refilled from the reservoir. The prepared sample was run for surface area analysis.

During surface area measurement of M003, extended degassing of a heated sample suggested that the media might be producing a gas. The glassy cenospheres of flyash may contain carbon dioxide and nitrogen in internal void spaces, which give them the lightweight quality (Cohen et al. 2003). Heating the glassy cenospheres should cause them to burst and release the gases. To test if the medium was producing oxygen, a simple experiment was developed. A large (1 11$)$ beaker was filled with ultra pure water. The water was boiled and then allowed to cool to $60^{\circ} \mathrm{C}$ and continuously bubbled with nitrogen gas to remove all dissolved oxygen. Nitrogen gas was then blown over the surface of the beaker to prevent atmospheric oxygen from reacting with oxygen-free water. The process was monitored with a dissolved oxygen probe that had been calibrated in air and water. Once all dissolved oxygen was removed, $10 \mathrm{~g}$ of medium was carefully added and the oxygen levels monitored.

Table 3 Analysis of flyash from Shannonbridge power station

\begin{tabular}{|c|c|c|c|c|c|}
\hline Constituents & $\mathrm{mg} \mathrm{kg}^{-1}$ & $\%$ volume & Atomic wt. & $\mathrm{mmol} \mathrm{kg}{ }^{-1}$ & $\mathrm{~mol} \mathrm{~kg}^{-1}$ \\
\hline Aluminum & 15,700 & 1.57 & 26.981 & 581.891 & 0.58 \\
\hline Arsenic & 101 & 0.01 & 74.921 & 1.34 & 0.001 \\
\hline Barium & 107 & 0.01 & 137.32 & 0.77 & 0.0007 \\
\hline Boron & 105 & 0.01 & 10.81 & 9.71 & 0.009 \\
\hline Cadmium & 1.78 & 0.00 & 112.41 & 0.01 & $1.58 \times 10^{-05}$ \\
\hline Calcium & 19,4000 & 19.40 & 40.07 & 4840.56 & 4.84 \\
\hline Iron & 51,700 & 5.17 & 55.87 & 925.74 & 0.92 \\
\hline Lead & 2.9 & 0.00 & 207.2 & 0.01 & $1.4 \times 10^{-05}$ \\
\hline Mercury & 0.08 & 0.00 & 200.59 & 0.0003 & $3.99 \times 10^{-07}$ \\
\hline Molybdenum & 8.9 & 0.00 & & & \\
\hline Phosphorous & 2,300 & 0.23 & 30.97 & 74.25 & 0.07 \\
\hline Selenium & 10 & 0.00 & 78.96 & 0.12 & 0.0001 \\
\hline Silica & 14,0000 & 14.00 & 28.08 & 4984.86 & 4.98 \\
\hline Sodium & 4,740 & 0.47 & 22.08 & 206.18 & 0.20 \\
\hline Tin & 890 & 0.09 & 118.71 & 7.49 & 0.007 \\
\hline Titanium & 49 & 0.00 & 47.88 & 1.02 & 0.001 \\
\hline
\end{tabular}


Medium-leaching test

Seventy-five grams of oven dried M003 were mixed with 11 of $18 \mathrm{MW}$ ultra pure water and regularly agitated once every few days over a period of $\sim 2.5$ months. Three water samples were decanted, filtered through $0.2 \mu \mathrm{m}$ anotop syringe filters. These samples were acidified to $2 \% \mathrm{HNO}_{3}$ and were analysed in triplicate by ICP-AES. The leaching test methodology followed the British standard leaching tests for concrete (British Standards Institute 2002).

\section{Results and discussion}

Flyash composition and development

The flyash from the Shannonbridge Ireland power station is calcium-rich, with silica, iron, aluminium, sodium, and phosphorous oxides as the major constituents (Table 3). Flyash from lignite and peat burning power stations has higher quantities of sulphur and calcium. A constituent in the flyash used in this study that caused concern is arsenic, which occurred at concentrations of $55 \mathrm{mg} \mathrm{kg}^{-1}$. Flyash is commonly reported to have elevated levels of toxic trace elements such as arsenic (Amrhein et al. 1996; Hajarnavis 2000; Cohen et al. 2003). The possible presence of arsenic and similar metals in flyash requires that the developed medium must have minimal leaching properties. The constituents of concern must be irreversibly bound within the medium. These properties also apply to contaminants that the medium is designed to remove from the groundwater.

To ensure that the flyash constituents would be irreversibly bound, other materials were sought that also have sorption and binding properties that would reduce the possibility of leaching of constituents. These materials were lime $(\mathrm{CaOH})$ and flocculation alum from drinking water treatment. Reardon and Della Valle (1997), in an attempt to recycle flyash, treated it with $\mathrm{CaOH}$ and formed an anionic clay, which due to its solid solution nature had the ability to substitute divalent and trivalent cations within its octahedral layers and the ability to substitute anions in the mineral interlayers. A synthetic flyash-based anionic clay could be stabilised with other ion scavenging 'waste' products such as industrial coagulants like iron(III) hydroxide. These coagulants degrade into amorphous hydrous metal oxides (Baltpurvins et al. 1996) that can adsorb cations (Axe and Anderson 1998). This product could be used as a granular permeable ion scavenging reactive barrier medium. This reactive medium would remove contaminant ammonium brines to prevent overloading of the sequential biological reactive barrier. The waste material could be solidified with low-quality high- $\mathrm{CaOH}$ Portland cement (Adasaka et al. 1998; Klemm 1998). Such cements have also been identified as $\mathrm{pH}$-dependent cation removers (Weng et al. 1996). The stabilised mixture could then be crushed to the desired size depending on the degree of permeability required.

\section{Ammonia removal}

The batch tests containing M003 and M004 (Table 1) of the variable media compositions suggest that as the flyash content rises, the amount of ammonium removed also rises. The removal of ammonium by $\mathrm{M} 003$ ranged from 6.11 to $8.65 \mathrm{M} \mathrm{kg}^{-1}$. The acidified $\mathrm{NaCl}$ supernatants that were used to wash the after it had been exposed to ammonium acetate had greater cation selectivity but managed to displace only $0.07 \mathrm{M} \mathrm{kg}^{-1}$ ammonium. Due to low performance, analysis of M004 was discontinued from the experiment.

The removal mechanism of ammonium by the M003 cannot be attributed to cation exchange. The initial decanted supernatant showed a dramatic reduction in the quantity of ammonium from solution to medium. The use of acidified $\mathrm{NaCl}$ to displace ammonium from the media was unsuccessful. If the sorption mechanism is not cation exchange, then the formation of synthetic zeolites from flyash is not occurring. One possible reason is that the modified flyash mixture $(10 \%$ hydrated lime, $10 \%$ alum and $80 \%$ ash) contains at least $10 \% \mathrm{CaO}$ causing the mixture to have a high $\mathrm{pH}$. The affinity of calcium for silicate may prevent the formation of synthetic zeolites by inhibiting the hydrolysis of silicates to silicic acid, which in turn reacts with tetrahydroxyaluminate species to form precursor gels and crystalline zeolites (Catalfamo et al. 1997). This would seem to contradict the statement by Deer et al. (1992) suggesting zeolites occur naturally at low pressure (at or close to surface) in conditions of high $\mathrm{pH}$. However, most of the lab-based experiments do not take into account the long time periods over which minerals would naturally accumulate. Although as Catalfamo et al. (1997) suggest, zeolites may not immediately form from the high calcium modified flyash, however, they can still act as a substrate that can remove ions from solution. This result is attributed to the alkaline effect that the substrate has on interaction with water causing metals to precipitate as hydroxides. The ion removal effect is comparable with removal capabilities of synthetic sodium flyash zeolites made under high pressure and temperature of $3 \mathrm{M} \mathrm{kg}^{-1}$ (Amrhein et al. 1996). The synthetic zeolite removes ions by exchange, whereas M003 irreversibly removes ions probably by increasing $\mathrm{pH}$ and causing precipitation of cation hydroxides. 
Lead and chromium removal

There is an initial dramatic removal of lead with $50 \%$ of total amount removed after $5 \mathrm{~min}$, after which there appears to be a linear reduction with square root time (Table 4; Fig. 1a, b). This initial dramatic reduction may be a precipitation event due to high $\mathrm{pH}$, after which there is continued reduced sorption. Higher levels of calcium and other basic oxides $\left(\mathrm{MgO}, \mathrm{CaO}, \mathrm{Na}_{2} \mathrm{O}\right.$ and $\mathrm{K}_{2} \mathrm{O}$ ) cause the flyash to be more alkaline in nature; this causes a dramatic $\mathrm{pH}$ rise when the flyash is added to water. The rise in $\mathrm{pH}$ causes cations that are normally soluble in groundwater to precipitate out (Cohen et al. 2003). However, an increase in $\mathrm{pH}$ alone is not enough to irreversibly remove cations. If the $\mathrm{pH}$ increases enough, the cations may return to solution in the form of carbonates (Langmuir 1997). The initial lead nitrate solution was $\sim 0.01 \mathrm{M}\left(2079 \mathrm{mg} \mathrm{kg}^{-1}\right.$ lead $)$. This was reduced by $85 \%$ over $4 \mathrm{~h}$ (Table 5 ). One gram of medium removed $0.00854 \mathrm{~mol}$ of lead from a $0.01 \mathrm{M}$ solution, equivalent to $8.544 \mathrm{~mol}$ of lead removed from solution per kilogram of medium. This result equates with the earlier batch testing, where M003 was calculated to have removed $8.65 \mathrm{M} \mathrm{kg}^{-1}$ ammonium. The recovered medium from the batch test was dried and

Table 4 Removal of lead from solution over time with M003

\begin{tabular}{lllrc}
\hline Time (min) & $\begin{array}{l}\text { Concentration } \\
\left(\mathrm{mg} \mathrm{kg}^{-1}\right)\end{array}$ & $\begin{array}{l}\text { Concentration } \\
(\mathrm{mol})\end{array}$ & $\%$ RSD & $\begin{array}{l}\mathrm{RSD} \\
\left(\mathrm{mg} \mathrm{kg}^{-1}\right)\end{array}$ \\
\hline 0 & $2,079.24$ & 0.01004 & 2.51 & 15.40 \\
1 & $1,167.33$ & 0.00563 & 7.89 & 105.4 \\
5 & $1,022.27$ & 0.00493 & 4.65 & 47.96 \\
10 & 928.28 & 0.00448 & 9.06 & 92.70 \\
15 & 806.06 & 0.00389 & 4.41 & 37.56 \\
30 & 743.67 & 0.00359 & 14.54 & 123.36 \\
60 & 654.23 & 0.00316 & 9.01 & 80.10 \\
120 & 437.40 & 0.00211 & 11.32 & 55.62 \\
240 & 308.85 & 0.00149 & 13.31 & 45.71 \\
\hline
\end{tabular}

reweighed (Table 5). The average increase in weight of the medium was $0.045 \mathrm{mg}$. The calculated average weight of lead removed from solution was $35.4 \mathrm{mg}$. The difference in weight between measured and calculated values may be attributed to the fact that the medium was dried at a temperature of $80^{\circ} \mathrm{C}$, which may not have completely driven off all water. Kumar et al. (2004) also report the adsorption of $\mathrm{Pb}$ on the surface of flyashbased zeolites.

Chromium exists in the form of dichromate anions $\left(\mathrm{Cr}_{2} \mathrm{O}_{4}\right)$ within potassium dichromate solution. The sorption test removed $28.2 \%$ of dichromate ions from a $0.0064 \mathrm{M}$ potassium dichromate solution over a period of $4 \mathrm{~h}$ (Table 6; Fig. 1c), suggesting that the medium also has an anion removal capability as postulated by Reardon and Della Valle (1997). However, the anion removal by $\mathrm{M} 003$ is not as substantial as cation removal, but is still significant at $1.8 \mathrm{M} \mathrm{kg}^{-1}$. The medium has versatility as both an anion and cation-removing agent. Unlike the interaction of $\mathrm{M} 003$ with lead nitrate, there is no immediate dramatic decrease of dichromate, but rather a gradual decrease, with the majority of dichromate removed after $50 \mathrm{~min}$. Unlike the lead nitrate there is no immediate 'precipitation event' followed by sorption, but probably just sorption of dichromate to the medium. Similar findings were reported by Cohen et al. (2003). Cohen attributed the lesser fixation properties to the hexavalent state of dissolved chromium, which is very soluble in basic conditions.

Effect of medium on dissolved oxygen content of ultra pure water

During surface area measurement of M003, extended degassing of a heated sample suggested that the media might be producing a gas. Over a period of $100 \mathrm{~min}$, dissolved oxygen levels ranged from 20 to $37 \%$
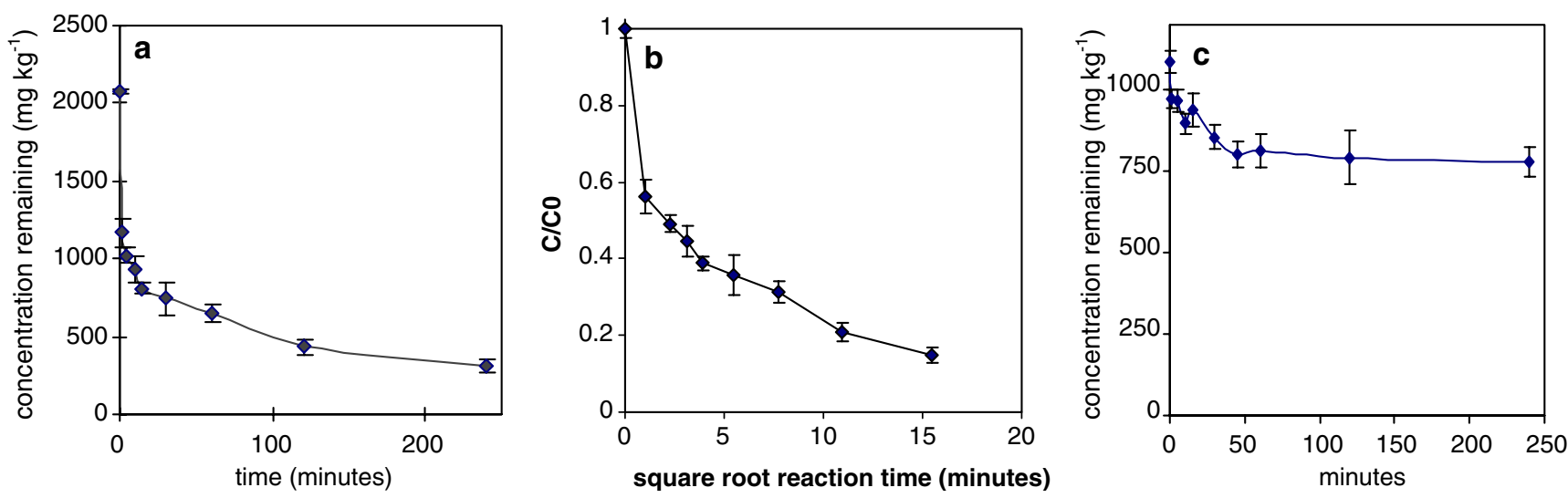

Fig. 1 a Removal of lead from solution over time by M003, b rate of removal of lead by M003 and $\mathbf{c}$ removal of chromium from solution by $\mathrm{M} 003$ 
Table 5 Comparison of weight of medium before and after sorption batch tests with lead

\begin{tabular}{llll}
\hline Sample & $1 \mathrm{mg} \mathrm{kg}^{-1}$ & $2 \mathrm{mg} \mathrm{kg}^{-1}$ & $3 \mathrm{mg} \mathrm{kg}$ \\
\hline Start weight & 1.0064 & 1.0037 & 1.0159 \\
Finish weight & 0.0572 & 1.0553 & 1.0495 \\
Difference & 0.0508 & 0.0516 & 0.0336 \\
& $0.045^{\mathrm{a}}$ & $0.01^{\mathrm{b}}$ & $22.43^{\mathrm{c}}$ \\
\hline
\end{tabular}

${ }^{\text {a Average value }}$

${ }^{\mathrm{b}} \mathrm{Standard}$ deviation

${ }^{\mathrm{c}} \mathrm{RSD} \%$

$\left(1.8 \mathrm{mg} \mathrm{kg}^{-1}\right)$. These values suggest that the medium would contribute dissolved oxygen to an anaerobic environment, thereby promoting aerobic degradation, which is an essential function within the sequenced biologic reactive barrier proposed at the Portadown site. The gas is probably due to the expelling of carbon dioxide or nitrogen from the glassy cenospheres as the flyash is heated (Cohen et al. 2003).

\section{Precipitations on flyash}

Scanning electron microscopic observations of modified flyash M003 revealed many small $(5-100 \mu \mathrm{m})$ spherical particles, or cenospheres, of flyash (Fig. 2). Chemical analysis reveals a composition mainly of $\mathrm{Ca}, \mathrm{Si}, \mathrm{Mg}, \mathrm{Al}$, $\mathrm{Fe}, \mathrm{Si}$ and $\mathrm{S}$ (Table 3 ). The spheres also have very small cubic-shaped, highly crystalline precipitates $(<1 \mu \mathrm{m})$ attached to them. These precipitates are similar in morphology to the highly crystalline cubic-shaped zeolites on flyash reported by Rayalu et al. (2001). Catalfamo et al. (1997) identified precipitation on flyash as calcium oxides. These oxides attached to the spheres are attributed by Catalfamo et al. (1997) as hindering zeolite growth. Catalfamo suggests that the glassy spheres of flyash act as nucleation centres for mineral growth. The prohibitive nature of calcium oxides reducing zeolite growth has been monitored only over very short time periods in laboratory experiments.

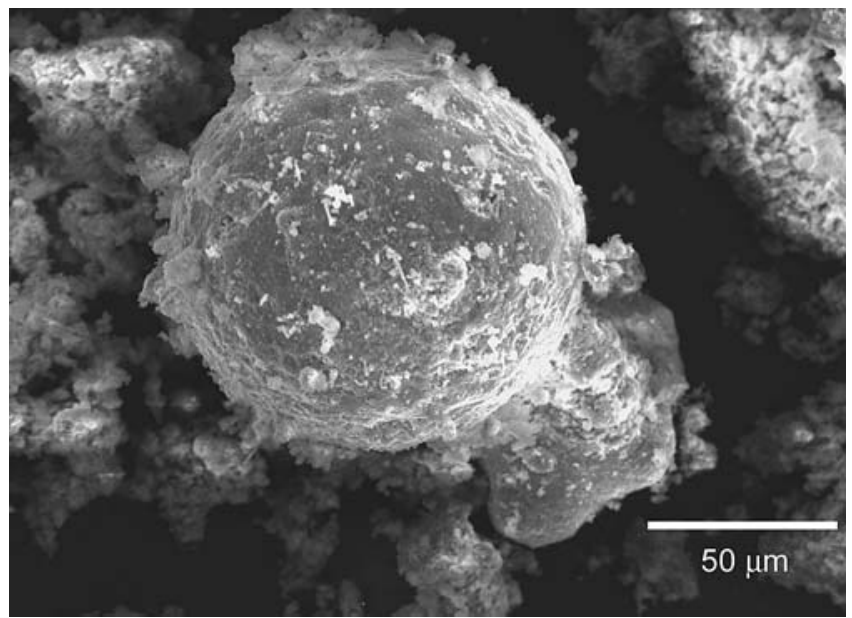

Fig. 2 A spherical glassy cenosphere of flyash

Modelling the medium

The output from the geochemical modelling (Table 7) shows that an anion-cation imbalance still existed within the dissolved constituents in the groundwater. This imbalance could be attributed to factors that were not considered, such as the presence of alkalinity, colloidal material, and of complex ligands that occur with cyanides (Theis et al. 1994). The measurement of sulphate by the KONE method gave greater imbalance to the charge difference than sulphate measurement by HPLC-IC. This result suggests that the modelling is in agreement with the HPLC analysis. The modelling assumes that equilibrium is being achieved within the subsurface environment. Although contamination has been occurring for the last 150 years this does not necessarily mean that the groundwater has achieved equilibrium with respect to the contamination.

\section{Surface area}

There is a reduction in specific surface area in both the column media compared to the fresh sample. In all

Table 6 Removal of chromium from solution over time with M003

\begin{tabular}{|c|c|c|c|c|c|}
\hline Time (min) & $\mathrm{Cr}\left(\mathrm{mg} \mathrm{kg}^{-1}\right)$ & Moles as $\mathrm{Cr}^{2+}$ & Moles as $\mathrm{Cr}_{2} \mathrm{O}^{4-}$ & $\%$ RSD & $\operatorname{RSD}\left(\mathrm{mg} \mathrm{kg}^{-1}\right)$ \\
\hline 0 & $1,085.31$ & 0.01044 & 0.006460 & 3.14 & 34.08 \\
\hline 1 & 972.49 & 0.00935 & 0.005789 & 2.91 & 28.34 \\
\hline 5 & 964.85 & 0.00928 & 0.005743 & 3.51 & 33.84 \\
\hline 10 & 897.10 & 0.00863 & 0.005340 & 3.62 & 32.45 \\
\hline 15 & 937.58 & 0.00902 & 0.005581 & 5.35 & 50.20 \\
\hline 30 & 855.77 & 0.00823 & 0.005094 & 4.20 & 35.98 \\
\hline 45 & 799.36 & 0.00769 & 0.004758 & 4.98 & 39.85 \\
\hline 60 & 812.21 & 0.00781 & 0.004835 & 6.46 & 52.49 \\
\hline 120 & 791.45 & 0.00761 & 0.004711 & 10.48 & 82.95 \\
\hline 240 & 778.85 & 0.00749 & 0.004636 & 5.69 & 44.33 \\
\hline
\end{tabular}


Table 7 Output from geochemical modelling

\begin{tabular}{lll}
\hline \multirow{2}{*}{ Output } & Groundwater & \\
\cline { 2 - 3 } & FMGP & Synthetic \\
\hline $\mathrm{pH}$ & 7.03 & 8.40 \\
Eh(mV) & 3.28 & \\
Equilibrium pe & 0.05 & 0.03 \\
Ionic Strength & 0.02 & $3.07 \times 10^{-2}$ \\
Sum of cations & $1.03 \times 10^{-2}$ & $3.05 \times 10^{-2}$ \\
Sum of anions & $1.28 \times 10^{-2}$ & 0.24 \\
Charge & 10.85 & \\
Difference $(\%)$ & & \\
\hline
\end{tabular}

cases, the medium with extensive biofilm showed the greatest decrease in surface area, pore specific volume and total adsorbed volume (Table 8). This medium also showed an increase in maximum cumulative area compared to the fresh medium and synthetic groundwater media, which may be attributed to the additional surface area of the biomass on the medium. Biofilm growth may be a factor in these differences, but the dissolved organic load within the Portadown groundwater may also be sorbing and reducing the specific surface area and increasing the cumulative area.

\section{Leaching tests}

The modified flyash removed ammonium, lead and chromium from the groundwater and did not inhibit microbiological activity, however, it failed the leaching test in our study. According to the laboratory-leaching test, arsenic, chromium and cadmium are at elevated levels for groundwater (Table 9). Although laboratory leaching cannot precisely reproduce field leaching behaviour, it can be used as estimation (Heebink and Hassett 2003). Therefore, these elevated levels of arsenic, chromium and cadmium have major implications for the barrier medium. The medium cannot allow the leaching of contaminants into groundwater. If the
Table 9 Leaching of cations from M003 after three months

\begin{tabular}{lcll}
\hline Cation & $\begin{array}{l}\text { Average of total } \\
\text { samples }(n=9) \\
\left(\mathrm{mg} \mathrm{kg}^{-1}\right)\end{array}$ & $\begin{array}{l}\text { Standard } \\
\text { deviation }\end{array}$ & $\begin{array}{l}\text { Relative } \\
\text { standard } \\
\text { deviation }(\%)\end{array}$ \\
\hline $\mathrm{As}$ & 0.49 & 0.39 & 4.43 \\
$\mathrm{Cr}$ & 0.24 & 0.30 & 3.42 \\
$\mathrm{Zn}$ & 0.09 & 0.14 & 1.57 \\
$\mathrm{Cd}$ & 0.06 & 0.08 & 0.90 \\
$\mathrm{~Pb}$ & 0.41 & 0.22 & 2.54 \\
$\mathrm{Fe}$ & 0.13 & 0.14 & 1.55 \\
$\mathrm{Si}$ & 0.38 & 0.11 & 1.23 \\
$\mathrm{Mn}$ & 0.00 & 0.00 & 0.03 \\
$\mathrm{Mg}$ & 0.04 & 0.01 & 0.17 \\
$\mathrm{Na}$ & 269.1 & 0.21 & 2.41 \\
$\mathrm{Cu}$ & 0.11 & 0.01 & 0.12 \\
$\mathrm{Ca}$ & 1769.2 & 0.54 & 6.02 \\
$\mathrm{Al}$ & 0.42 & 0.17 & 1.94 \\
\hline
\end{tabular}

medium constantly leaches contaminants, it cannot be used within a PRB. When the analysis of the control blank is compared, it is apparent that cross-contamination of cations is occurring. Chromium was not detected in the initial analysis of the flyash, but is found within the medium leachate. There is probably some cross-contamination of chromium within the ICP OES. However, arsenic and cadmium, which were present in the initial analysis, are probably being leached from the flyash. Arsenic and cadmium may be present as coatings or small solid particles on the surface of flyash which leaves them venerable to leaching (Querol et al. 2001). Additionally, as the flyash weathers or breaks down during use in the PRB it can release these heavy metals. Appreciable amounts of arsenic and chromium have been leached from coal flyash with pure water (Llorens et al. 2001).

\section{Conclusions and recommendations}

A modified flyash was developed to test a cheap, highly sorptive granular material that did not inhibit microbiological activity. Batch tests showed that a high-
Table 8 Results of surface area calculations

\begin{tabular}{lccl}
\hline & Fresh Medium & $\begin{array}{l}\text { Medium in synthetic } \\
\text { groundwater } \\
\left(1,000 \mathrm{mg} \mathrm{kg}^{-1}\right) \text { after } \\
1,400 \text { pore volumes }\end{array}$ & $\begin{array}{l}\text { Medium in contaminated } \\
\text { groundwater } \\
(\text { Test Pit 11) after } \\
1,400 \text { pore volumes }\end{array}$ \\
\hline Monolayer volume $\left(\mathrm{cm}^{3} / \mathrm{g}\right)$ & 1.74 & 0.25 & 0.18 \\
Specific surface area $\left(\mathrm{m}^{2} / \mathrm{g}\right)$ & 7.57 & 1.12 & 0.81 \\
C value for BET equation & -82.00 & -12.55 & -17.97 \\
Correlation factor & 0.99 & 0.97 & 0.95 \\
Pore specific volume $\left(\mathrm{cm}^{3} / \mathrm{g}\right)$ & 0.0098 & 0.0077 & 0.0063 \\
Pore specific volume $\mathrm{P} / \mathrm{P0}$ & 0.95 & 0.95 & 0.95 \\
Total adsorbed volume $\left(\mathrm{cm}^{3} / \mathrm{g}\right)$ & 17.22 & 17.78 & 8.81 \\
Cumulative area max $\left(\mathrm{m}^{2} / \mathrm{g}\right)$ & 5.07 & 5.16 & 0.91 \\
Pore volume max $\left(\mathrm{cm}^{3} / \mathrm{g}\right)$ & 0.024 & 0.028 & \\
\hline
\end{tabular}


flyash composition medium could remove $8.65 \mathrm{~mol}$ of ammonium contaminant for every kilogram of medium. This rate is more than double the removal capacity of high-temperature and -pressure synthetic zeolites that have been made from flyash. The modified CEC procedure showed that cation exchange is not the major removal mechanism. The medium also adsorbed anions as well as cations, but not to the same degree. SEM analysis also showed new crystalline growth, but growth did not occur quickly enough to enable productive zeolite formation. The initial mechanism for cation removal is probably precipitation, followed by sorption. Sorption is probably the only mechanism for the removal of dichromate anions. Biofilm growth on the medium could be a major factor in the comparative surface area reduction that was observed between real and synthetic contaminant groundwaters. Leaching tests show that the medium is not suitable as a longterm barrier material.

Some further work is needed. Rate constants that could be used to model anion and cation removal need to be determined. The long-term effects of the medium interacting with groundwater also need to be examined. In a PRB designed to last for decades, slow zeolite growth over that period may allow a predominately sorbing medium to slowly transform into an exchanging one during the lifespan of the barrier. The capacity of the medium to produce dissolved oxygen over time should be determined, and if necessary, the rate of oxygen dissolution reduced to promote an aerobic environment within the barrier. Development of an experiment that allows sampling over time and not just at the end of a column experiment would allow a correlation in the development of biofilms and reduction of surface area.

\section{References}

Adasaka W, Treasouthick SW, West PB (1998) Solidification and stabilization of wastes using Portland cement. Portland Cement Association

Amrhein C, Haghnia GH, Kim TS, Mosher PA, Gagajena RC, De La Torre L (1996) Synthesis and properties of zeolites from coal fly ash. Environ Sci Technol 30:735-742

American Public Health Association (APHA) (1992) Standard methods of water and wastewater, 18 th edn. American Public Health Association, American Water Works Association, Water Environment Federation publication. APHA, Washington DC

Axe L, Anderson PR (1998) Intraparticle diffusion of metal contaminants. In: Jenne E (ed) Adsorption of metals by Geomedia: variables, mechanisms, and model applications, chap 8. Academic, New York, pp 193-208

Baltpurvins KA, Burns RC, Lawrance GA, Stuart AD (1996) Effect of $\mathrm{Ca}^{2+}$, $\mathrm{Mg}^{2+}$, and anion type on the aging of iron(III) hydroxide precipitates. Environ Sci Technol 31:1024-1032

Benner SG, Blowes DW, Gould WD, Herbert RB Jr, Ptacek CJ (1999) Geochemistry of a permeable reactive barrier for metals and acid mine drainage. Environ Sci Technol 33:2793-2799

Blowes DW, Ptacek CJ, Benner SG, McRae CWT, Bennett TA, Puls RW (2000) Treatment of inorganic contaminants using permeable reactive barriers. J Contam Hydrol 45:121
Blowes DW, Ptacek CJ, Jambor JL (1997) In situ remediation of chromate contaminated groundwater using permeable reactive walls. Environ Sci Technol 31:3348-3357

British Standards Institution/European Standard Organisation (2002) Tests for chemical properties of aggregates. Preparation of eluates by leaching of aggregates. BS EN 1744-3. $12 \mathrm{p}$

Catalfamo P, Di Pasquale S, Corigliano F, Mavilia L (1997) Influence of the calcium content on the coal fly ash features in some innovative applications. Resour Conserv Recycl 20:119-125

Cohen H, Lederman E, Werner M, Pelly I, Polat M (2003) Synergetic effect of coal flyash as a scrubber to acidic wastes of the phosphate fertilizers industry. In: International ash utilization symposium for applied energy research. University of Kentucky, Paper \#50

Deer WA, Howie RA, Zussman J (1992) An Introduction to the rock-forming minerals, 2nd edn. Wiley, New York, p 696

Department of Transportation (1998) Methods of test for the chemical analysis of Portland cement, fly ash, pozzolan, and blended cement. California Engineering Service Center. P 4

Fenchel T, Blackburn T (1978) The nitrogen cycle. In: Bacteria and mineral cycling. Academic, New York, pp 101126

Gu B, Watson DB, Wu L, Phillips DH, White DC, Zhou JZ (2002) Microbiological characteristics in a zero-valent iron reactive barrier. Environ Monit Assess 77:293-309
Guerin TF, Horner S, McGovern T, Davey B (2002) An application of permeable reactive barrier technology to petroleum hydrocarbon contaminated groundwater. Water Res 36:15-24

Gustaffoson JP (2001) Visual Minteq ver. 2.0. Department of Land and Water Resource Engineering, Kungul Tekniska Hogskola, Sweden: Available at: http://www. Lwr.kth.se/English/OurSoftware/Vminteq/index.htm\# download

Hajarnavis MR (2000) Studies of trace metals in acidic flyash. J Sci Ind Res 59:381-388

Heebink LV, Hassett DJ (2003) Coal fly ash trace element mobility in soil stabilization. In: International ash utilization symposium for applied energy research. University of Kentucky, Paper \#64

Interdepartmental Committee on the Redevelopment of Contaminated Land (ICRCL) (1989) Notes on the redevelopment of gasworks sites; Her Majesty's Stationary Office, London

Kempers AJ, Zweers A (1986) Ammonium determination in soil extracts by the salicylate method. Commun Soil Sci Plan 17:715-723

Klemm WA (1998) Ettringite and oxyanion. Substitute ettringites - their characterization and applications in the fixation of heavy metals. Portland Cement Association

Kumar P, Rayalu S, Dhopte SM (2004) Flyash based zeolite-A: a suitable sorbent for lead removal. Indian J Chem Technol 11:227-233 
Langmuir D (1997) Aqueous environmental geochemistry. Prentice Hall, Englewood Cliffs, $600 \mathrm{pp}$

Lin C-F, Lo S-S, Lin H-Y, Lee Y (1998) Stabilisation of cadmium contaminated soils using synthesized zeolite. J Hazard Mater 60:217-226

Llorens JF, Fernandez-Turiel JL, Querol X (2001) The fate of trace elements in a large coal-fired power plant. Environ Geol 40:409-416

Majcenovic Ch, Barth-Wirsching U (2000) The use of Hungarian clinoptilolitecontaining tuff for the synthesis of zeolites F, G, W, Na-P1, A, and ZSM-5. In: Colella C, Mumpton FA (eds) Natural zeolites for the third millennium. De Frede, Editore, Napoli, Italy, pp 403 414

O'Hannesin SF, Gillham RW (1998) Long term performance of an in situ 'iron wall' for remediation of VOCs. Groundwater 36:164-170

Park J-B, Lee S-H, Lee J-W, Lee G-H (2002) Lab scale experiments for permeable reactive barriers against contaminated groundwater with ammonium and heavy metals using clinoptililote (01-29B). J Hazard Mater 28:1-15
Perić J, Trgo M, Vukojević Medvidović N (2004) Removal of zinc, copper and lead by natural zeolite - a comparison of adsorption isotherms. Water Res 38:1893-1899

Phillips DH, Gu B, Watson DB, Roh Y, Liang L, Lee SY (2000) Performance evaluation of a zerovalent iron reactive barrier: mineralogical characteristics. Environ Sci Technol 34:4169-4176

Phillips DH, Gu B, Watson DB, Roh Y (2003a) Mineralogical characteristics and transformations during long-term operation of a zero-valent iron reactive barrier. J Environ Qual 32:2033-2045

Phillips DH, Watson DB, Gu B, Roh Y (2003b) Impact of sample preparation on mineralogical analysis of iron reactive barrier materials. J Environ Qual 32:1299-1305

Puls RW, Paul CJ, Powell RM (1999) The application of in situ permeable reactive (zero-valent iron) barrier technology for the remediation of chromate-contaminated groundwater: a field test. Appl Geochem 14:989-1000

Querol X, Umana JC, Alastuey A, Ayora C, Lopez-Soler A, Plana F (2001) Extraction of soluble major and trace elements from fly ash in open and closed leaching systems. Fuel 80:801-813

Rayalu SS, Udhoji JS, Munshi KN, Hasan MZ (2001) Highly crystalline zeolite-a form of flyash of bituminous and lignite coal combustion. J Hazard Mat B88:107-121
Reardon EJ, Della Valle S (1997) Anion sequestering by the formation of anionic clays: lime treatment of fly ash slurries. Environ Sci Technol 31:12181223

Roh Y, Lee SY, Elless MP (2000) Characterization of corrosion products in the permeable reactive barriers. Environ Geol 40:184-194

Srinivasan A, Grutzech MW (1999) The adsorption of $\mathrm{SO}_{2}$ by zeolites synthesized from flyash. Environ Sci Technol 33:1464-1469

Theis TL, Young TC, Huang M, Knutsen KC (1994) Leachate characteristics and composition of cyanide-bearing wastes from manufactured-gas plants. Environ Sci Technol 28:99-106

Weng CH, Huang CP, Allen HE, Leavens PB, Sanders PF (1996) Chemical interactions between $\mathrm{Cr}(\mathrm{VI})$ and hydrous concrete particles. Environ Sci Technol 30:371-376

Wood RB, McAtemney CF (1996) Constructed wetlands for waste water treatment: The use of laterite in the bed medium in phosphorus and heavy metal removal. Hydrobiologia 340:323-331 